УДК 597 (282.247.326.8)

О. О. Христов, В. М. Кочет

Дніпропетровський національний університет ім. Олеся Гончара

\title{
ХАРАКТЕРИСТИКА ІХТІОФАУНИ РІКИ ДНІПРО В РАЙОНІ МІСТА ДНІПРОПЕТРОВСЬК
}

\begin{abstract}
Наведена ретроспективна характеристика іхтіофауни Дніпровського водосховища в районі міста Дніпропетровськ. На основі багаторічних досліджень установлено закономірності розвитку угруповань риб, здійснено оцінку впливу комплексу антропогенних чинників на іхтіоценоз, запропоновано заходи щодо оптимізації життсдіяльності риб на сучасному етапі розвитку міста Дніпропетровськ.
\end{abstract}

\author{
O. O. Khristov, V. M. Kochet
}

Oles' Gonchar Dnipropetrovsk National University

\section{CHARACTERISTICS OF ICHTHYOFAUNA OF THE DNIEPER RIVER IN THE VICINITY OF DNIPROPETROVS'K}

Retrospective characteristics of ichthyofauna of the Dniprovs'ke reservoir in the vicinity of the Dnipropetrovs' $k$ city are presented. On the basis of perennial observations the regularities of fish communities' development were determined, the influence of complex of anthropogenic factors on ichthyocenosis was assessed, and measures for optimization of fish life activity at the present stage are proposed.

\section{Ветуп}

Місто Дніпропетровськ розташоване по обидва береги р. Дніпро, в межах верхньої ділянки Дніпровського водосховища та гирла найбільшої його притоки - p. Самаpa. У даний час на р. Дніпро створений каскад водосховищ. Історія досліджень іхтіофауни акваторії ріки в районі м. Дніпропетровськ нерозривно пов'язана 3 дослідженнями, що проводились як до створення каскаду водосховищ [1; $3 ; 4 ; 16]$, так і після функціонування ріки у зарегульованому режимі $[5 ; 6 ; 12 ; 14]$.

На початку 1970-х років, у період інтенсифікації впливу антропогенних чинників, упроваджується система іхтіологічного моніторингу, створюється мережа природоохоронних акваторій [2;8]. Після перебудови в Україні соціально-економічної структури з'являються нові аспекти досліджень - визначення впливу сучасних факторів на усталеність іхтіоценозу, у тому числі любительського рибальства, з метою розробки заходів оптимізації навантаження на популяції риб $[10 ; 11 ; 15]$. Актуальність проведених досліджень обумовлена інтенсифікацією процесу освоєння прибережної мілководної зони безпосередньо в межах міста.

Мета досліджень - установити сучасний стан іхтіофауни ділянки Дніпровського водосховища в районі м. Дніпропетровськ, розробити заходи збереження біологічного різноманіття іхтіофауни, підтримання процесу ії усталеного функціонування.

(C) О. О. Христов, В. М. Кочет, 2008 


\section{Матеріал і методи досліджень}

Комплексні іхтіологічні проби були відібрані у період 1976-2007 років практично на всіх типах біотопів, розповсюджених у межах акваторії Дніпровського водосховища, приуроченої до м. Дніпропетровськ. Відібрано 340 інтегральних проб у прибережжях, проаналізовано 850 сіткопідйомів. Організація досліджень, відбір і подальша обробка отриманого матеріалу проводилися за загальноприйнятими іхтіологічними методиками $[8 ; 11 ; 15]$.

\section{Результати та їх обговорення}

Деградація природних нерестовищ на акваторії Дніпровського (озера ім. Леніна, Запорізького) водосховища як штучно створеної водойми, погіршення умов ефективного відтворення аборигенних видів риб, зменшення рівня біорізноманіття в районах максимальної трансформації та низка інших негативних факторів обумовили необхідність детальних досліджень стану іхтіофауни всіх ділянок акваторії цієї водойми, у тому числі й у межах м. Дніпропетровськ. Дніпровське водосховище за тривалістю та потужністю дії комплексу антропогенних чинників і рівнем трансформації посідає одне з перших місць в Україні. Навіть при дотриманні комплексу рекомендованих природоохоронних дій режим спрацювання води внаслідок роботи ГЕС вступає у протиріччя з історично сформованим життєвим циклом риб. 3 інших негативних факторів, що впливають на іхтіоценоз акваторії в межах м. Дніпропетровськ, відмічається вкрай високий рівень забудови прибережної зони, великі площі відторгнених, масштабно трансформованих прибереж, надходження широкого спектра забруднювачів разом із комунально-побутовими та промисловими стічними водами. Мілководдя, що мають пріоритетне значення для відтворення водних живих ресурсів у районі міста, практично повністю зосереджені в межах острівних систем лівобережжя р. Дніпро й у гирлі Самарської затоки. У правобережжі вони частково збереглися переважно у районі гребного каналу (житловий масив «Перемога», збудований на території Мандриківської заплави). Міське будівництво значно скоротило площі природного відтворення (нерестовищ), відбулося погіршення умов нагулу молоді риб.

Одним із вагомих формівних факторів, що впливають на іхтіоценоз даної акваторії, є любительське (аматорське) рибальство, у більшості своїй - неорганізоване. Починаючи 3 1990-х років зниження загальної зайнятості населення й ускладнення соціально-економічної ситуації, разом із незаконним (браконьєрським) виловом, обумовило пріоритетний вплив на іхтіоценоз. Орієнтовна чисельність рибалок-аматорів тільки в межах м. Дніпропетровськ у даний час перевищує 100 тис. чоловік. Саме тут розташована більшість місць, придатних для лову. Аматорське рибальство базується на вилові, в основному, молоді та статево незрілих екземплярів ресурсних риб, особливо у період їх активного росту (улітку). Усе це, разом зі зниженим рівнем природного відтворення, призвело до зменшення обсягів поповнення популяцій риб на ділянках акваторії у межах міста.

У складі фауни риб р. Дніпро в межах м. Дніпропетровськ за весь період іхтіологічних досліджень зареєстровано 60 видів, що відносяться до 15 родин (табл.). Аборигенний (вихідний) іхтіоценоз до початку гідробудівництва та зарегулювання стоку р. Дніпро нараховував 47 видів риб і включав також прохідні види з родини Acipenseridae. Після створення Дніпровського водосховища (1931р.) корінна перебудова структури гідроекосистеми призвела до загального погіршання стану його іхтіофауни. На сучасному етапі (починаючи з 2001 р.) іхтіокомплекс дослідженої акваторії нараховує 40 видів риб, що відносяться до 11 родин. Домінує родина Cyprinidae - 
17 видів риб, менш численні представники родини Gobiidae - 8 видів, Percidae - 4 види, інші родини обмежуються 1-2 представниками. При загальному домінуванні у Дніпровському водосховищі видів лімнофільного екологічного комплексу, на ділянках у межах м. Дніпропетровськ зареєстровані також представники реофільного комплексу. У репродуктивному аспекті домінують види фітолімнофільного комплексу. У трофічному плані переважають види-бентофаги, але на дослідженій ділянці суттєво представлені також види-планктофаги.

Видовий склад іхтіофауни Дніпровського (Запорізького) водосховища

Таблиичя в районі м. Дніпропетровськ

\begin{tabular}{|c|c|c|c|c|c|}
\hline \multirow{2}{*}{ Види риб } & \multicolumn{5}{|c|}{ Періоди } \\
\hline & $\mathrm{I}$ & II & III & IV & $\mathrm{V}$ \\
\hline 1 & 2 & 3 & 4 & 5 & 6 \\
\hline \multicolumn{6}{|c|}{ Родина 1. Осетрові (Acipenseridae) } \\
\hline $\begin{array}{l}\text { 1. Білуга чорноморська } \\
\text { (Huso huso ponticus Salnikov et Malyatskij, 1934) }\end{array}$ & + & - & - & - & - \\
\hline 2. Стерлядь (Acipenser ruthenus Linnaeus, 1758) & + & + & + & - & - \\
\hline $\begin{array}{l}\text { 3. Осетер російський } \\
\text { (Acipenser gueldenstaedtii Brandt et Ratzeburg, 1833) }\end{array}$ & + & - & - & - & - \\
\hline 4. Севрюга (Acipenser stellatus Pallas, 1771) & + & - & - & - & - \\
\hline \multicolumn{6}{|c|}{ Родина 2. Вугрові (Anguillidae) } \\
\hline 5. Вугор річковий (Anguilla anguilla Linnaeus, 1758) & + & + & + & - & - \\
\hline \multicolumn{6}{|c|}{ Родина 3. Оселедцеві (Clupeidae) } \\
\hline $\begin{array}{l}\text { 6. Тюлька чорноморсько-азовська } \\
\text { (Clupeonella cultriventris Nordmann, 1840), 1958* }\end{array}$ & - & + & + & + & + \\
\hline $\begin{array}{l}\text { 7. Оселедець чорноморсько-азовський прохідний } \\
\text { (Alosa pontica Eichwald, 1838), 1961* }\end{array}$ & + & + & + & + & + \\
\hline \multicolumn{6}{|c|}{ Родина 4. Коропові (Cyprinidae) } \\
\hline 8. Ялець європейський (Leuciskus leuciscus Linnaeus, 1758) & + & + & + & - & - \\
\hline 9. Головень звичайний (Leuciscus cephalus Linnaeus, 1758) & + & + & + & + & + \\
\hline $\begin{array}{l}\text { 10. Бобирець звичайний (дніпровський) } \\
\text { (Leuciscus borysthenicus Kessler, 1859) }\end{array}$ & + & + & - & - & - \\
\hline 11. В'язь (Leuciscus idus Linnaeus, 1758) & + & + & + & + & - \\
\hline 12. Плітка звичайна (Rutilus rutilus Linnaeus, 1758) & + & + & + & + & + \\
\hline \begin{tabular}{|l|} 
13. Вирезуб причорноморський \\
(Rutilus frisii frisii Nordmann, 1840)
\end{tabular} & + & - & - & - & - \\
\hline 14. Краснопірка (Scardinius erythrophthalmus Linnaeus, 1758) & + & + & + & + & + \\
\hline 15. Підуст звичайний (Chondrostoma nasus Linnaeus, 1758) & + & + & + & - & - \\
\hline $\begin{array}{l}\text { 16. Бистрянка російська } \\
\text { (Alburnoides bipunctatus rossicus Berg, 1924) }\end{array}$ & + & - & - & - & - \\
\hline 17. Верховодка звичайна (Alburnus alburnus Linnaeus, 1758) & + & + & + & + & + \\
\hline 18. Верховка звичайна (Leucaspius delineatus Heckel, 1843) & + & + & + & + & + \\
\hline 19. Рибець звичайний (Vimba vimba vimba Linnaeus, 1758) & + & + & + & - & - \\
\hline 20. Плоскирка європейська (Blicca bjoerkna Linnaeus, 1758) & + & + & + & + & + \\
\hline 21. Лящ звичайний (Abramis brama Linnaeus, 1758) & + & + & + & + & + \\
\hline 22. Клепець європейський (Abramis sapa Pallas, 1814) & + & + & + & - & - \\
\hline 23. Синець звичайний (Abramis ballerus Linnaeus, 1758) & + & + & + & - & - \\
\hline 24. Білизна звичайна (Aspius aspius Linnaeus, 1758) & + & + & + & + & + \\
\hline $\begin{array}{l}\text { 25. Товстолобик білий } \\
\text { (Hypophthalmichthys molitrix Valenciennes, 1844), 1971* }\end{array}$ & - & - & + & + & + \\
\hline
\end{tabular}


Продовження табл.

\begin{tabular}{|c|c|c|c|c|c|}
\hline 1 & 2 & 3 & 4 & 5 & 6 \\
\hline $\begin{array}{l}\text { 26. Товстолобик строкатий } \\
\text { (Aristichthys nobilis Richardson, 1846), 1971* }\end{array}$ & - & - &.+ & + & + \\
\hline 27. Чехоня звичайна (Pelecus cultratus Linnaeus, 1758) & + & + & + & + & + \\
\hline 28. Гірчак європейський (Rhodeus amarus Bloch, 1782) & + & + & + & + & + \\
\hline $\begin{array}{l}\text { 29. Чебачок амурський } \\
\text { (Pseudorasbora parva Temminck \& Shlegel, 1846), 1992* }\end{array}$ & - & - & - &.+ & + \\
\hline 30. Пічкур звичайний (Gobio gobio gobio Linnaeus, 1758) & + & + & + & - & - \\
\hline $\begin{array}{l}\text { 31. Марена дніпровська } \\
\text { (Barbus barbus borysthenicus Dybowski, 1862) }\end{array}$ & + & + & - & - & - \\
\hline $\begin{array}{l}\text { 32. Білий амур } \\
\text { (Ctenopharyngodon idella Valenciennes, 1844), 1971* }\end{array}$ & - & - & + & + & + \\
\hline $\begin{array}{l}\text { 33. Короп (сазан) європейський } \\
\text { (Cyprinus carpio Linnaeus, 1758) }\end{array}$ & + & + & + & + & + \\
\hline $\begin{array}{l}\text { 34. Карась звичайний (золотий) } \\
\text { (Carassius carassius Linnaeus, 1758) }\end{array}$ & + & + & + & + & - \\
\hline $\begin{array}{l}\text { 35. Карась сріблястий } \\
\text { (Carassius auratus gibelio Bloch, 1782), 1970* }\end{array}$ & - & - & + & + & + \\
\hline 36. Лин озерний (Tinca tinca, Linnaeus, 1758) & + & + & + & + & + \\
\hline \multicolumn{6}{|c|}{ Родина 5. В'юнові (Cobitidae) } \\
\hline 37. Щипавка звичайна (Cobitis taenia Linnaeus, 1758) & + & + & + & + & + \\
\hline 38. В’юн звичайний (Misgurnus fossilis Linnaeus, 1758) & + & + & + & + & + \\
\hline \multicolumn{6}{|c|}{ Родина 6. Баліторові (Balitoridae) } \\
\hline $\begin{array}{l}\text { 39. Вусатий слиж європейський } \\
\text { (Barbatula barbatula Linnaeus, 1758) }\end{array}$ & + & + & + & - & - \\
\hline \multicolumn{6}{|c|}{ Родина 7. Ікталурові (Ictaluridae) } \\
\hline $\begin{array}{l}\text { 40. Канальний сом плямистий } \\
\text { (Ictalurus punctatus Rafinesque, 1818) }\end{array}$ & - & - & - & + & + \\
\hline \multicolumn{6}{|c|}{ Родина 8. Сомові (Siluridae) } \\
\hline 41. Сом європейський (Silurus glanis Linnaeus, 1758) & + & + & + & + & + \\
\hline \multicolumn{6}{|c|}{ Родина 9. Щукові (Esocidae) } \\
\hline 42. Щука звичайна (Esox lucius Linnaeus, 1758) & + & + & + & + & + \\
\hline \multicolumn{6}{|c|}{ Родина 10. Миневі (Lotidae) } \\
\hline 43. Минь річковий (Lota lota Linnaeus, 1758) & + & + & + & - & - \\
\hline \multicolumn{6}{|c|}{ Родина 11. Атеринові (Atherinidae) } \\
\hline $\begin{array}{l}\text { 44. Атерина чорноморська } \\
\text { (Atherina boyeri pontica Eichwald, 1831), 1990* }\end{array}$ & - & - & - & + & + \\
\hline \multicolumn{6}{|c|}{ Родина 12. Колючкові (Gasterosteidae) } \\
\hline $\begin{array}{l}\text { 45. Колючка мала південна } \\
\text { (Pungitius platygaster Kessler, 1859) }\end{array}$ & + & + & + & + & + \\
\hline $\begin{array}{l}\text { 46. Триголкова колючка звичайна } \\
\text { (Gasterosteus aculeatus Linnaeus, 1758), 1977* }\end{array}$ & - & - & + & + & + \\
\hline \multicolumn{6}{|c|}{ Родина 13. Голкові (Syngnathidae) } \\
\hline $\begin{array}{l}\text { 47. Морська голка пухлощока чорноморська } \\
\text { (Syngnathus nigrolineatus Eichwald, 1831) }\end{array}$ & + & + & + & + & + \\
\hline \multicolumn{6}{|c|}{ Родина 14. Окуневі (Percidae) } \\
\hline 48. Судак звичайний (Stizostedion lucioperca Linnaeus, 1758) & + & + & + & + & + \\
\hline $\begin{array}{l}\text { 49. Судак волзький (берш) } \\
\text { (Stizostedion volgensis Gmelin, 1788), 1972* }\end{array}$ & - & - & + & + & + \\
\hline 50. Окунь звичайний (Perca fluviatilis Linnaeus, 1758) & + & + & + & + & + \\
\hline 51. Йорж звичайний (Gymnocephalus cernuus Linnaeus, 1758) & + & + & + & + & + \\
\hline 52. Йорж носар (Gymnосерhalus acerinus Gueldenstaedt, 1774) & + & + & + & - & - \\
\hline
\end{tabular}


Закінчення табл.

\begin{tabular}{|c|c|c|c|c|c|}
\hline 1 & 2 & 3 & 4 & 5 & 6 \\
\hline \multicolumn{6}{|c|}{ Родина 15. Бичкові (Gobiidae) } \\
\hline 53. Бичок-кругляк (Neogobius melanostomus Pallas, 1814) & + & + & + & + & + \\
\hline 54. Бичок-головач (Neogobius kessleri Gunter, 1861) & + & + & + & + & + \\
\hline 55. Бичок-пісочник (Neogobius fluviatilis Pallas, 1814) & + & + & + & + & + \\
\hline $\begin{array}{l}\text { 56. Бичок-гонець } \\
\text { (Neogobius gymnotrachelus Kessler, 1857), 1970* }\end{array}$ & - & - & + & + & + \\
\hline $\begin{array}{l}\text { 57. Бичок-мартовик (кнут) } \\
\text { (Mesogobius batrachocephalus Pallas, 1814), 1995* }\end{array}$ & - & - & - & + & + \\
\hline 58. Бичок-цуцик (Proterorhinus marmoratus Pallas, 1814) & + & + & + & + & + \\
\hline $\begin{array}{l}\text { 59. Бичок-пуголовочка Браунера } \\
\text { (Benthophiloides brauneri Beling et Iljin, 1927), 2005* }\end{array}$ & - & - & - & - & + \\
\hline $\begin{array}{l}\text { 60. Бичок-пуголовка зірчаста } \\
\text { (Benthophilus stellatus Sauvage, 1874) }\end{array}$ & + & + & + & + & + \\
\hline Всього видів & 47 & 43 & 48 & 41 & 40 \\
\hline
\end{tabular}

Примітки: I - період до будівництва Дніпрогесу; II - період 1931-1963 років, після зарегулювання стоку і до створення каскаду водосховищ; Ш - період 1964-1980 років, функціонування в режимі каскаду та початок інтенсивного антропогенного навантаження; IV - період 1981-2000 років, функціонування в режимі максимального антропогенного навантаження; V - період 2001-2007 років, функціонування в режимі стабільного навантаження;* - дата першої реєстрації виду на ділянці за сучасними дослідженнями.

До аборигенного (вихідного) іхтіокомплексу відносяться 26 видів риб. Із 14 видів риб, що поповнили іхтіофауну даної ділянки водосховища, 6 увійшли до іiі складу в результаті проведення інтродукційних заходів, 8 видів $є$ наслідком саморозселення. Серед видів-інтродуцентів присутні представники далекосхідної іхтіофауни, що не відтворюються (A. nobilis Ricard., H. molitrix Valen., C. idella Valen.). Чисельність цих видів підтримується за рахунок постійного зариблення. Два види повністю пройшли акліматизацію до умов водосховища, нарощують чисельність у прибережжях (P. parva Schlegel., C. auratus gibelio Bloch.) і у відкритій частині водойми (C. auratus gibelio Bloch.). Один вид - випадковий вселенець (I. punctatus Ricard.), створив локальну популяцію, його відтворення здійснюється у підігрітих водах Придніпровської ТЕС. Саморозселенці проникли 3 понизь р. Дніпро та Каховського водосховища. Більшість із них належить до родини Gobiidae і короткоциклових пелагічних видів (C. cultriventris Nordmann i A. boyeri pontica Eich.). За показником чисельності у складі іхтіоценозу дослідженої акваторії переважають види-еврибіонти, найпристосованіші до умов існування у несприятливих умовах.

Промисловий лов на акваторії водосховища в межах м. Дніпропетровськ практично не здійснюється, за винятком експедиційного лову при наявності промислових скупчень. Користувачами освоєна здебільшого гирлова частина Самарської затоки. У зв'язку з тим, що іхтіофауна $є$ рухливим компонентом водних екосистем і активно пересувається на значну відстань, видовий склад більшості ділянок досліджуваної акваторії має ознаки одноманітності, за винятком ділянки, що прилягає до гирла Самарської затоки. Ця ділянка відрізняється збільшеними рівнями біорізноманіття та чисельності. Дані показники наближені до районів, що піддаються меншому впливу антропогенних чинників (середня ділянка Дніпровського водосховища).

Найбільше трансформовані акваторії, розташовані по правому берегу р. Дніпро. Особливо це стосується ділянки між Амурським залізничним мостом і островом Монастирський. Тут прибережна зона повністю забудована (міська набережна та інші споруди). Крім того, сюди надходять стоки зливових колекторів і деяких підприємств міста, інші забруднювачі, що мають великий уміст органічної речовини. На цій ділянці 
відбувається нагул молоді риб, у тому числі і тих, що мають ресурсну (промислову) цінність. У місцях надходження стоків спостерігаються угруповання даних видів, а також концентрація пелагічних видів, у першу чергу - A. alburnus L. Відмічається нерест винятково прибережноводних видів, які охороняють або виношують ікру (представники родин Syngnathidae, Gasterosteidae, Gobiidae). Нересту інших видів заважає відсутність зарослих мілководь, фактор забруднення й занепокоєння. Промислове рибальство тут не здійснюється. Розвинутий винятково неорганізований любительський лов. 3 усіх видів, що зареєстровані в межах міста Дніпропетровськ (40), на цій ділянці зареєстровано 37. Відсутні 3 види: L. delineatus Heckel., T. tinca L. та M. fossilis L. Міжнародний, європейський, обласний охоронний статус мають 19 видів риб, один вид потребує охорони на регіональному рівні.

Ділянка правобережжя, розташована між островом Монастирський і Південним автодорожним мостом, також значно трансформована, але в районі гребного каналу (житловий масив «Перемога») відмічаються умови для нересту й нагулу риб ресурсної категорії (A. brama L., R. rutilus L., C. auratus gibelio Bloch., S. erythrophthalmus L., L. cephalus L., P. fluviatilis L., E. lucius L., B. bjoerkna L. тощо). На даній ділянці зустрічаються всі види риб, зареєстровані в межах міста (40 видів), у тому числі 21 вид має охоронний статус, а один потребує охорони на регіональному рівні.

Ділянки лівобережжя трансформовані меншою мірою, ніж правобережжя. Найбільшій антропогенній трансформації, внаслідок впливу промислово-побутових стоків, щільної забудови та інших факторів, піддана ділянка, розташована між Амурським залізничним і Усть-Самарським мостами. Виняток складає зона мілководь навколо дамби Усть-Самарського мосту та прилеглих островів. Указані прибережжя відіграють роль місць відтворення переважно прибережноводних видів, а також короткоциклових (A. alburnus L.) і деяких промислових видів, що $є$ невибагливими до умов нересту (P. fluviatilis L., C. auratus gibelio Bloch., $R$. rutilus L., S. erythrophthalmus L.). Найцінніші природні комплекси збереглися в районі, що прилягає до Усть-Самарського мосту (острови Олексіївський, Шевський та суміжні прибережжя). Тут нерестують і здійснюють подальший нагул цінні промислові види (A. brama L., S. lucioperca L. і Cyprinus carpio L.). Відмічається також нагул перших вікових груп E. lucius L., L. cephalus L., B. bjoerkna L., S. glanis L. Загалом тут реєструються усі види риб, поширені в межах міста, у тому числі 21 вид має охоронний статус, а один вид потребує охорони на регіональному рівні. У межах зазначеної акваторії здійснюється промисловий лов користувачами водних живих ресурсів, що базуються у населених пунктах Стара Ігрень і Одинківка. Крім того, ділянка має значення для любительського рибальства.

Ділянка, розташована між Усть-Самарським і Південним мостами, за морфологічними характеристиками наближена до попередньо розглянутого району, але тут площі захищених мілководь значно менші. Це обумовлює зниження іiі цінності для нагулу й відтворення представників іхтіоценозу. Разом із тим, ця ділянка продуктивніша порівняно 3 правобережжям. 3 усіх видів, зареєстрованих у межах міста тут, не реєструються тільки два - T. tinca L. та M. fossilis L. Охоронний статус мають 20 видів риб, а один потребує охорони на регіональному рівні.

Акваторія, розташована у гирловій частині Самарської затоки (між Ігренським та Усть-Самарським мостами), найважливіша для усталеного функціонування іхтіокомплексу не тільки Дніпровського водосховища, а і всієї течії р. Самара. У зв'язку з цим у даному районі заборонений промисловий лов і любительське рибальство у період 31 березня до 1 вересня. Під час нерестових міграцій тут концентруються плідники риб, проходить нерест ряду видів, у тому числі тих, що належать до групи ресурсно важли- 
вих. Улітку відбувається міграція й скат молоді всіх зареєстрованих аборигенних видів, ії нагул. Крім того, ця ділянка $є$ місцем зимівлі риб (зимувальна яма). Тому у зимовий період тут заборонено будь-яке рибальство. На цій ділянці зустрічаються всі види риб, зареєстровані в межах міста, у тому числі 21 вид має охоронний статус, а один потребує охорони на регіональному рівні.

\section{Висновки}

У складі іхтіофауни Дніпровського (Запорізького) водосховища в межах м. Дніпропетровськ зареєстровано 60 видів риб, представників 15 родин. До створення водосховища нараховувалося 47 видів. У подальшому видовий склад коливався 3 тенденцією до зменшення. В останні 20 років відмічено збільшення видового складу.

Видовий склад дослідженої акваторії на сучасному етапі (2001-2007 роки) нараховує 40 видів риб, що належать до 11 родин. Серед них домінують види лімнофільного комплексу. До аборигенного (вихідного) іхтіокомплексу відносяться 26 видів риб. Інші 14 видів з'явилися у складі іхтіофауни у процесі проведення робіт з інтродукції та в результаті саморозселення.

Умови існування більшості видів вихідного (аборигенного) комплексу характеризуються як незадовільні. У першу чергу це обумовлено практично повною відсутністю якісних природних нерестовищ, нерест здійснюється вимушено, його ефективність низька. Разом із тим, відмічається підвищена чисельність видів із категорії еврибіонтів, найбільш невибагливих. У прибережжях збільшується до загрозливих значень чисельність окремих видів - випадкових вселенців.

Умови нагулу риб, особливо молоді, на більшості досліджених ділянок також несприятливі, хоча у деяких біотопах за рахунок підвищеної продукції кормових організмів спостерігається збільшення чисельності та біомаси функціонально загрозливих видів риб, які мають широкий спектр пристосувань Це - ознака порушення процесу усталеного існування іхтіокомплексу.

У межах м. Дніпропетровськ найменше трансформованими є ділянки лівобережжя p. Дніпро, у тому числі гирлова частина Самарської затоки. Вони виконують основну функцію природних нерестовищ і місць нагулу молоді. На правобережжі роль нагулу і, частково, відтворення риб виконують акваторія гребного каналу та суміжні ділянки.

Для збереження в межах м. Дніпропетровськ акваторій, що забезпечують умови існування риб на всіх стадіях розвитку (нерест, нагул, зимівля), необхідно розробити комплекс природоохоронних і рибоводно-меліоративних заходів, які передбачають обмеження господарської діяльності, особливо в мілководній прибережній зоні.

\section{Бібліографічні посилання}

1. Белинг Д. Е. Дніпро та його рибні багатства. - К.: АН УРСР, 1935. - 164 с.

2. Булахов В. Л. Некоторые аспекты адаптации тарани к экстремальным условиям водохранилищ в процессе ее натурализации / В. Л. Булахов, О. А. Христов, С. Н. Тарасенко // Механизмы адаптаций растений и животных к экстремальным факторам среды. Тез. докл. V Ростов. обл. научно-практ. школы-семинара. - Ростов-на-Дону, 1987. - С. 151-152.

3. Емельяненко П. С. Рыбы Днепровского бассейна // Вестник рыбопромышленности. Петроград, 1914. - № 10/11. - 52 с.

4. Кесслер К. Ф. Путешествие с зоологической целью к северному берегу Черного моря и в Крым в 1858 году. - К., 1860. -248 с.

5. Коблицкая А. Ф. К вопросу восстановления речной ихтиофауны в районе Днепровских порогов // Вестн. научно-исслед. ин-та гидробиологии. - 1948. - Т. 8. - С. 43-47. 
6. Короткий Й. І. Ххтіофауна порожистої частини р. Дніпра та їі зміни під впливом побудування греблі Дніпрельстану // Вісн. Дніпропетр. гідробіол. станції. - 1937. - Т. 2.- С. 133-141.

7. Кузнецов В. Л. Количественный учет молоди в водохранилищах и озерах (Методические подходы и возможности) // Типовые методики исследования продуктивности видов рыб в пределах их ареалов. - Вильнюс, 1985. - Ч. 5. - С. 26-35.

8. Мельников Г. Б. Характеристика распределения основных промысловых рыб в Ленинском водохранилище на Днепре в условиях каскада / Г. Б. Мельников, В. Л. Булахов, С. Н. Тарасенко // Биол. основы управл. повед. рыб в связи с применением рыбозащ. и рыбопропускных сооружений. Матер. симпоз. - М.: Наука, 1971. - С. 85-88.

9. Методика збору і обробки іхтіологічних і гідробіологічних матеріалів з метою визначення лімітів промислового вилучення риб із великих водосховищ і лиманів України. - К.: IРГ УААН, 1998. $-47 \mathrm{c}$.

10. Новицкий Р. А. Использование количественных и качественных результатов рыболовных соревнований в научных целях // Рыбное хозяйство Украины. - 2004. - № 1. - С. 35-37.

11. Новицкий Р. А. Ихтиофауна Днепровского водохранилища на современном этапе / Р. А. Новицкий, О. А. Христов, В. Н. Кочет // Структ. и функц. роль жив-го населения в природн. и трансформ. экосистемах. Тез. І Междунар. конф. - Д.: ДНУ, 2001. - С. 51-52.

12. Паншин Т. Б. До іхтіофауни р. Дніпра в районі від Дніпропетровська до Нікополя // Зб. праць Дніпрянської біол. ст. - 1931. - № 6. - С. 112-138.

13. Правдин И. Ф. Руководство по изучению рыб (преимущественно пресноводных). - М.: Пищ. пром-сть, 1966. -376 с.

14. Чаплина А. М. Ихтиофауна Самарского водохранилища после его восстановления // Beстник Днепропетровского научно-исследовательского института гидробиологии. - К.: КГУ, 1955. - Т. 11.- С. 155-162.

15. Христов О. А. Эколого-экономические аспекты устойчивого использования водных живых ресурсов (на примере Днепровского водохранилища) / О. А. Христов, В. Н. Кочет, Р. А. Новицкий // Пресноводная аквакультура в Центрально-Восточной Европе: достижения и перспективы. Матер. Междунар. конф. - К.: ІРГ, 2000. - С. 207-211.

16. Güldenstaedt A. Reisen dur Russland und Caucasischen Gebürge. - St. Petersburg, 1787. - R. 1.

Надійшла до редколегії 01.02.2008 